\title{
NECESSARY STEP FROM "ICT" TO "LTK” IN FOREIGN LANGUAGE TEACHING AND LEARNING
}

\author{
Maja Veljković Michos, \\ Lora Petronić Petrović
}

\author{
${ }^{1}$ Singidunum University \\ 32 Danijelova Street, Beograd, Serbia \\ ${ }^{2}$ Singidunum University \\ Faculty of Business Valjevo, \\ Valjevo, Serbia
}

\section{Correspondence:}

Maja Veljković Michos

e-mail:

mveljkovic@singidunum.ac.rs

\begin{abstract}
:
When we speak about new technologies and education, the first thing that comes to our mind is information and communications technologies or ICT. Technological progress and development of information systems have inevitably led to the incorporation of ICT in the teaching-learning methodologies. With the use of new digital educational content in our classrooms, temporal and spatial boundaries of those two processes have been transcended. However, teachers of foreign languages face the fact that the incorporation of ICT in the teaching procedure doesn't imply necessary improvement of knowledge and language skills of students. Therefore, it is essential to develop digital competences of both teachers and students, which will further ensure adjustment of teaching-learning process to modern circumstances. Hence, it is necessary to introduce and apply a new concept in the teaching methodology - "LTK - Learning Technologies Knowledge", which emphasizes the application of digital or virtual materials for the enhancement of teaching, learning and assessment. In this paper, we will propose certain useful guidelines and tools that can ensure proper application of ICT in our educational environment, thus improving students' knowledge and skills while learning a foreign language.
\end{abstract}

Key words:

ICT, LTK, teaching and learning, foreign language, Web tools.

\section{INTRODUCTION}

Technological innovations have provided creation of new educational environments and new learning experiences. In this sense, computer skills of teachers should be developed according to technical and educational progress. Moreover, our role as teachers is fundamental in this process, since we have to be those who know how to apply ICT in order to help our students learn a foreign language using modern technology.

On the other hand, our students are mainly more proficient than us in using the Internet and they carry out different online activities daily (surf, chat, download videos and songs, communicate with friends on social platforms, read magazine or newspaper articles etc). Consequently, teachers should consider this advantage and make our students more responsible for their own progress by putting it to work for learning (Gonzalez Romero 2007: 161).

Nevertheless, not all activities performed with use of ICT are valuable for the teaching and learning process. It is clear that new technologies alone can neither produce educational innovation, nor the fact that we are using them makes us better teachers or students. For that reason, the role of the teacher 
in the teaching process is essential - not in the way to teach our students to use technology (since, as we previously said, they do that even better than we do), but to teach them how to use it properly in order to learn a foreign language.

\section{ICT OR LTK?}

Our main objective in using technology as an improvement in teaching and learning process is to make our students better and more independent learners, as well as to ensure that they acquire or improve both learning and language skills. At this point, we start talking about LTK Learning Technologies and Knowledge, as, so far, the final stage of teaching in digital era. First the teaching was about ICT, and then through ICT, until we arrived to LTK, where our goal is that our students learn language with technology (Vivancos: 2008).

Hence we can say that from the Society of Information where we began to handle ICT, with the intention to manage and collect generated information, we turned to the Society of Knowledge, where the significance of technology is not anymore just gathering and using information. Its importance is now transformed into knowledge - using it in the proper way. This means that technologies provide access to knowledge and learning, and it leads us to technologies of Society of Knowledge which are the LTK (López 2013: 3).

Once this distinction is done, teachers need to evaluate every new tool they find in order to determine how it fits into their curriculum and their didactic methodology. Before incorporating ICT in the process of teaching and learning, it is essential to understand their purpose, not just their form. In achieving this, teachers should ask themselves the following useful questions:

1. Will ICT encourage learning?

2. Will ICT bring new possibilities and improve the efficiency of procedures that we are already using?

3. Do they fit into our didactic methodology?

4. Have we considered the possible risks?

5. Do they fulfill the needs of our students?

6. Do we know how to use them properly?

7. Do we need trainings, seminars and courses to learn how to use them properly?

If the answers to these proposed questions (or others that teachers may consider appropriate) are positive, we are referring to ICT that can be incorporated into the process of teaching and learning, or LTK. It further means that it is necessary to determine the most appropriate methodology to be incorporated in our classroom, in order to develop digital competences of both teachers and students, and thus diminish the existing gap between teachers, considered digital immigrants and students, considered digital natives (Prensky: 2001).

One of the appropriate methodologies that we found very helpful was designed by Mishra and Koehler in 2006, a model known by its acronym TPACK (Technological Pedagogical Content Knowledge).

According to this model, the way to improve a good use of ICT and LTK in educational environments is based and depends on the knowledge of the teachers. Therefore, language teachers should not focus exclusively on the educational and linguistic contents to be developed and learnt, but should also have knowledge about technology, which will allow them to select and manage the Web tools and resources in order to create the content they want to exploit in the classroom. This, of course, presumes that teachers have already acquired and implemented knowledge in didactic methodologies which is appropriate for teaching a foreign language in their lessons, those of learning by doing, experimenting, of collaborative and cooperative nature, which allow that the classrooms become shared learning spaces for building up skills and knowledge.

\section{INTEGRATION OF ICT IN CURRICULUM (TPCK MODEL)}

The idea of TPCK (Technological Pedagogical Content Knowledge) was developed by professors at the University of Michigan and it became a tool that prepares teachers to successfully implement technology in classrooms (Mishra and Koehler 2006:1017-1054).

According to this model, expertise in smart adoption of technology by teachers and students is required in order to accomplish effective teaching and learning process. Moreover, it is primarily aimed at teachers and demands more specific skills from them, especially because they are sometimes faced with barriers that discourage them from using ICT in the classroom or creating additional materials with them. In that sense, there are seven combinations of analysis offered by TPCK model.

These different combinations allow planning different teaching strategies in order to improve the process of language learning, taking into consideration more aspects: content-pedagogy-technology:

- CK (Content Knowledge)

- PK (Pedagogical Knowledge)

- TK (Technological Knowledge)

- CPK (Pedagogical Content Knowledge). 
- TCK (Technological Content Knowledge).

- TPK (Technological Pedagogical Knowledge)

- TPCK (Technological Pedagogical Content Knowledge)

The next table presents UNESCO ICT Competency Standards for Teachers (ECD-ICT), which represent a reference model for integration of ICT in curriculum (url: UNESCO ECD-TIC).

\section{WEB TOOLS FOR LEARNING TECHNOLOGY KNOWLEDGE}

Considering the previous table of Standards of ICT skills for teachers, as language teachers at university, we asked ourselves what the best way would actually be to use web tools in our teaching and how we should use them to make our students, as we previously stated, better and more independent learners. The answer laid in the fact that there

\begin{tabular}{|c|c|c|c|}
\hline & Basic ICT knowledge & $\begin{array}{c}\text { Knowledge Deepening } \\
\text { Approach }\end{array}$ & Knowledge Application \\
\hline Pedagogy & $\begin{array}{l}\text { Integrate ICT, "knowing" } \\
\text { where, when (also when not) } \\
\text { and how to use (ICT) digital } \\
\text { technology activities and pres- } \\
\text { entations in the classroom }\end{array}$ & $\begin{array}{l}\text { Solution of complex problems. } \\
\text { Structuring tasks, guiding the } \\
\text { comprehension and support- } \\
\text { ing collaborative projects. }\end{array}$ & $\begin{array}{l}\text { Self-management. Forming } \\
\text { learning processes, structuring } \\
\text { situations in which students } \\
\text { apply their acquired skills and } \\
\text { helping students to acquire } \\
\text { new skills and knowledge }\end{array}$ \\
\hline
\end{tabular}

\begin{tabular}{ll}
\hline & ICT literacy. Gaining ICT \\
& skills and knowledge from web \\
& sources, in order to use ICT \\
Teacher & in acquiring additional knowl- \\
Professional & edge about their subjects, be- \\
Development & sides pedagogy, contributing \\
& to their own professional de- \\
& velopment.
\end{tabular}

Basic knowledge. Have solid knowledge of curriculum standards (study plan) from their subjects as well as the ability to integrate the use of ICT by students and these standards in the curriculum.

\section{Management and guidance. Create complex projects, col- laborate with other teachers and make use of networks in order to have an access to information, colleagues and experts, to support their own professional development.}

Application of knowledge. Have exhaustive knowledge of their subject and be able to apply it flexibly in a variety of situations.
Teacher in the role of a student. Show willingness to try, learn continuously and use ICT in order to create professional knowledge communities.
Curriculum and Assessment

Organization and Administration
Standard lecture rooms. Be able to use ICT during activities with the entire class, small groups and individually. Ensure equal access of students to ICT.
Collaborative groups. Being able to create flexible learning environments in classrooms. In these environments, teacher may integrate student-centered activities and flexible application of ICT, in order to support collaboration.
Competencies of the XXI century. Know the complex cognitive processes, know how students learn and understand the difficulties they can face.
Organization of learning. Being able to play a leading role in the formation of their colleagues, as well as to promote development and implementation of the vision in their school as a community based on innovation and lifelong learning, enhanced by ICT.
Basic tools. Know the basic function of hardware and software, as well as productivity applications, the Internet browser, a communication program, a multimedia presenter and management applications.
Complex tools. Knowing a variety of applications and specific tools and should be able to use flexibly in different situations based on problems and projects.
Widespread technology. Ability to create knowledge communities based on ICT, and capacity to use them in order to support the development of students' skills in both ways: creation of knowledge and permanent and reflexive learning.

Table 1. Standards of ICT skills for teachers (Adapted from UNESCO, 2008). 
existed such abundance of web tools that we could search for those matching each type of intelligence, as well as with different strategies for learning a foreign language.

Being a skill, comprised of four subskills (listening, speaking, reading and writing), learning a foreign language implies practicing these skills on a regular basis. In this fact we found our next directive - to look for a web tool that would support everyday practice of a language. At the beginning there were plenty of them we could choose from; those that were not meant for teaching at all, such as blogs, wikis, even social networks, such as Facebook, Twitter or Instagram, until appearance of the one specially developed for teaching/learning purposes, MOODLE platform. It is based on pedagogical principles, and it offers us possibilities of adjusting teaching and learning methods from our classrooms to virtual world. It means that it not only helps us continue communication with our students after classes, but it helps us continue interaction (individual, pair or group work) among themselves even though they are not sitting in the same room. The only pitfall of this tool that we had to overcome was to make our students "visit" it regularly.

The best way to match content and technology was found in creating different activities and exercises that implement strategies needed for successful learning. In presenting different web tools for this purpose, we would start with those used for learning vocabulary, as we consider vocabulary the basis for foreign language learning.

In order to make our students good vocabulary learners, we enlivened strategies for learning and integrating it in already existing knowledge, such as using word/ flash cards with QUIZLET (http://quizlet.com/), mnemonics with MIXBOOK (http://www.mixbook.com/), word searchers with PUZZLE MAKER http://www.puzzle-maker.com/ WS/, crosswords with CROSSWORD PUZZLE GAMES http://www.crosswordpuzzlegames.com/create.html, LISTEN AND WRITE (http://www.listen-and-write.com/ for practicing spelling and dictations, as well as VOKI http:// www.voki.com/ for practicing pronunciation (or speaking and listening skills).

Furthermore, we propose tools that can be used for improving all four language skills, as well as strategies for their learning. In the first place we put WORDLE http://www. wordle.net/, which can be used for creation of warm-up, lead-in to wrap up activities. Then, there are several tools for creating mind maps, of which we will mention https:// www.text2mindmap.com/, http://www.wisemapping.com/ and https://bubbl.us/. For creating posters we suggest using GLOGSTER http://edu.glogster.com/, POPPLET http:// www.popplet.com/ or SMORE https://www.smore.com/. One of the very useful tools is http://www.eslvideo.com, a site where interactive quizzes can be created, as well as KAHOOT https://getkahoot.com/, for creating online quizzes, discussions or surveys.

\section{CONCLUSION}

When we refer to advantages of applying ICT into the process of teaching and learning foreign languages, we consider the fact that this is a complex procedure of developing the language skills of reading, listening, writing and speaking for which the foundation is teh knowledge of vocabulary and grammar rules. With ICT integrated properly in curricula, it has become possible to create exercises for practicing all previously mentioned. In addition to doing exercises created by teachers, students also participate in creating exercise themselves, and in such a way become responsible for their own learning and are able to follow their own progress.

The importance of ICT is now transformed into knowledge - using it in proper way. This means that technologies provide access to knowledge and learning that lead us to technologies of Society of Knowledge which are the LTK.

Web-tools have become very useful and necessary LTK strategy in the process of teaching and learning a foreign language, completely integrated in the demands of modern didactic methodology.

If used properly, ICT or LTK become powerful tool for encouraging students for autonomous and effective learning. In this paper, we presented examples from our own practice, as a brief review of different activities we are using them for, with the aim of making our suggestions basic guidelines for some future work and research.

\section{REFERENCES}

Beck, S.E. (2008) "Why It's a Good Idea to Evaluate Web Sources: Evaluation Criteria".

(http://lib.nmsu.edu/instruction/evalcrit.html) retrieved on March $15^{\text {th }} 2016$

González López-Romero (2007) González López-Romero, Elisa: "Las TIC en la enseñanza del español presencial y on-line". Actas XLV (AEPE), 161-168. (http://cvc.cervantes.es/ensenanza/biblioteca_ele/ aepe/pdf/congreso_45/congreso_45_15.pdf) retrieved on March 15th 2016

Lopez, Mónica (2013) "From ICTs to the Learning Technologies Knowledge (LTK): the importance of digital educational content", Revista DIM (Didáctica, Innovación y Multimedia). № 27, ISSN: 1699-3748, December 2013 (http://www.pangea.org/dim/revista.htm) retrieved on March 15th 2016 
Mishra, P. y Koehler, J. (2006) Technological Pedagogical Content Knowledge: A Framework for Teacher Knowledge. Teachers College Record, 108 (6), 10171054. (http://punya.educ.msu.edu/publications/ journal_articles/mishra-koehler-tcr2006.pdf) retrieved on March 15 th

National Capital Language Resource Center (NCLRC) The essentials of language teaching, Developing listening activities <http://www.nclrc.org/essentials/ listening/developlisten.htm $>$ retrieved on March $24^{\text {th }}$ http://nclrc.org/essentials.

National Capital Language Resource Center (NCLRC) (n.d.). The essentials of language teaching, Strategies for developing speaking skills <http://www.nclrc. org/essentials/speaking/stratspeak.htm $>$ retrieved on March $24^{\text {th }}$

Peachy, Nik. Web 2.0 tools for teachers. (E-book) (http:// www.scribd.com/doc/19576895/Web-20- Toolsfor-Teachers) retrieved on March $24^{\text {th }} 2016$

Peachy, Nik. 10 Teacher Development Task for Web 2.0 Tools, (http://nikpeachey.blogspot. com/2009/11/10-teacher-development-task-forweb-20.html), Peachy Nik's Learning Technology Blog, 24. XI 2009, retrieved on March $24^{\text {th }} 2016$

Peachy, Nik. Top tools for e-learning (http://nikpeachey. blogspot.com/2008/03/top-tools-for-e-learning. html), Nik's Learning Technology Blog, 24. III 2008, retrieved on March $24^{\text {th }} 2016$
Petronić Petrović, L. (2011) Web 2.0 alati i učenje španskog jezika u velikim grupama putem rešavanja zadataka, master rad, Univerzitet u Beogradu Filološki fakultet

Prensky, Marc. "Digital Natives Digital Immigrants”, On the Horizon (MCB University Press, Vol. 9 No. 5, October 2001

Scott Thornbury (2002) How to teach vocabulary, Longman, Essex

Teaching speaking (The National Capitol Language Resource Center) (http://www.nclrc.org/essentials/ speaking/spindex.htm) retrieved on March $24^{\text {th }}$ 2016

TPACK Framework (http://open.byu.edu/ipt287/tpackframework/) retrieved on March 15th 2016

UNESCO ECD-TIC. Web del proyecto Estándares en Competencias TIC para Docentes. (http://www. unesco.org/en/competency-standards-teachers) retrieved on March 15th 2016

UNESCO (2008). Estándares UNESCO de Competencia en TIC para Docentes. (http://www.eduteka. org/pdfdir/UNESCOEstandaresDocentes.php) retrieved on March 15th 2016

Vivancos, Jordi (2008) Tratamiento de la información y competencia digital. Madrid: Alianza Editorial. 